\title{
ANALISA DAN PERANCANGAN SISTEM INFORMASI ADMINISTRASI DATA PRIBADI DAN NILAI MAHASISWA DI PERGURUAN TINGGI (STUDI KASUS UNIVERSITAS KEBANGSAAN BANDUNG)
}

\author{
Asti Herliana \\ Amik BSI Bandung \\ Sekolah Internasional No.1-6 Antapani, Bandung 40282 \\ Asti.ala@bsi.ac.id
}

\begin{abstract}
This research produce an information system about college students administrative procedure especially the personal data and value process. Administrative process at the sprout of education or college are one of the important factor of the organization activity. Very quick and appropriately information is the main thing that should be given by the administrator. A computerized system is the answer to solve the problems that occur. with the computerization system, the work that performed daily by the administrator becomes easier because the administrator just need to enter the data into the computer and then when the administrator need the data, it can be searched by using keywords to obtain the necessary data in a short time. The reason why the visual-based programme was use in this research is because the visual-based programme was user friendly or easy to used by the administrator. Beside that, visual-based programme have a high aesthetic value so that the administrator can operate the program with a good view.
\end{abstract}

Keywords : Administration Information System, College, Personal Data, Value Data

\begin{abstract}
Abstrak - Penelitian ini menghasilkan sebuah sistem informasi tentang prosedur administrasi mahasiswa terutama membahas tentang data pribadi dan proses nilai. Proses administrasi di bidang pendidikan atau perguruan tinggi adalah salah satu faktor penting dari kegiatan organisasi. Penyajian informasi yang cepat dan tepat guna adalah hal utama yang harus diberikan oleh administrator. Sebuah sistem komputerisasi adalah jawaban untuk memecahkan masalah yang terjadi. Dengan sistem yang terkomputerisasi, pekerjaan yang dilakukan setiap hari oleh administrator menjadi lebih mudah karena administrator hanya perlu memasukkan data ke dalam komputer dan kemudian ketika administrator membutuhkan data, dapat dicari dengan menggunakan kata kunci untuk mendapatkan data yang diperlukan dalam waktu singkat. Alasan mengapa program berbasis visual digunakan pada penelitian kali ini adalah karena program berbasis visual adalah program yang user friendly atau mudah digunakan. Selain itu, program berbasis visual memiliki nilai estetika yang cukup tinggi sehingga administrator dapat mengoperasikan program dengan pandangan yang baik
\end{abstract}

Keywords : Administration Information System, College, Personal Data, Value Data

\section{PENDAHULUAN}

Sistem administrasi merupakan salah satu kegiatan yang wajib hadir didalam kegiatan sebuah organisasi seperti lembaga pendidikan dan perguruan tinggi. Hal ini dikarenakan dalam kegiatan objek utamanya yakni mahasiswa diawali oleh administrasi dan diakhiri kelak setelah memperoleh kelulusan juga oleh administrasi.
Dalam penanganan administrasi, terutama yang berhubungan dengan pelayanan terhadap mahasiswa tentu memiliki beberapa permasalahan. Salah satu permasalahan yang timbul adalah ketika mahasiswa ingin mengetahui kesesuaian data pribadi yang tercantum pada database kampus dengan data pribadi yang dimiliki mahasiswa ataupun ketika mahasiswa ingin mengetahui informasi perkuliahan dan nilai yang didapatkan mahasiswa pada suatu matakuliah dimana 
informasi yang dibutuhkan harus diberikan pihak administrasi dalam waktu yang singkat.

Pada sistem yang berjalan pada Universitas Kebangsaan Bandung, sistem administrasinya sudah menggunakan sistem yang terkomputerisasi, namun untuk penggunaan programnya masih menggunakan program lama yakni Foxpro versi 2.6 yang berbasis DOS, dimana dari segi tampilan programnya masih bersifat statis dan tidak jarang pada saat input data mengalami proses loading yang cukup memakan waktu.

Berdasarkan permasalahan dan analisis sistem yang dilakukan, maka tujuan dilakukan penelitian ini adalah untuk membuat suatu sistem komputerisasi yang lebih efektif dan efisien dilihat dari segi tingkat kecepatan dan ketepatan data yang diberikan pihak administrasi kepada mahasiswa.

\section{LANDASAN TEORI}

\section{Administrasi}

Secara etimologis, administrasi berasal dari bahasa Yunani administrare yang artinya adalah melayani atau membantu. Dalam bahasa Inggris administrasi (administration) dapat diartikan sebagai melayani dengan baik. Secara sempit dalam bahasa Belanda, administrasi (administratie) diartikan sebagai pekerjaan tulis menulis atau ketatausahaan/ kesekretarisan[2].

Administrasi adalah keseluruhan proses kerjasama antara dua orang manusia atau lebih yang didasarkan pada rasionalitas tertentu untuk mencapai tujuan yang telah ditentukan sebelumnya[5]. Pengertian administrasi juga dikemukakan oleh Van Der Schroeff dimana definisi administrasi adalah merupakan seluruh himpunan catatan-catatan mengenai perusahaan dan peristiwa-peristiwa perusahaan untuk keperluan pimpinan dan penyelenggaraan perusahaan[2].

\section{Sistem Informasi}

Sistem adalah bagian-bagian yang saling berkaitan yang beroperasi bersama untuk mencapai beberapa sasaran atau maksud[4]. Dalam pengertian lain, sistem juga diartikan sebagai kerangka dari prosedur-prosedur yang berhubungan yang disusun sesuai dengan suatu skema yang menyeluruh untuk melaksanakan suatu kegiatan atau fungsi utama dari perusahaan[1].

Informasi dapat didefinisikan sebagai kumpulan data yang relevan dan mempunyai arti yang menggambarkan suatu kejadiankejadian atau kegiatan-kegiatan[3].
Berdasarkan pengertian sistem dan informasi, maka dapat disimpulkan sistem informasi adalah seperangkat unsur-unsur yang saling berhubungan dan berinteraksi mengolah data untuk kemudian dijadikan memiliki nilai untuk yang membutuhkan demi mencapai tujuan bersama. Dalam pengertian lain sistem informasi diartikan sebagai suatu cara yang sudah ditentukan untuk menyediakan data yang memiliki nilai yang dibutuhkan oleh sebuah organisasi untuk beroperasi dengan cara yang sukses dan untuk organisasi bisnis dengan cara yang menguntungkan[10]

\section{METODE PENELITIAN}

Metode pengembangan sistem merupakan cara yang dilakukan untuk membuat sistem yang berjalan mengalami perubahan ke arah yang lebih baik. Metode pengembangan sistem yang digunakan dalam penelitian ini adalah metode Waterfall dimana metode ini dijabarkan pada gambar 1. Alasan penggunaan metode ini adalah karena sistem yang digunakan adalah sistem sistem yang statis atau tidak mengalami perubahan format database setiap harinya, atau akan mengalami perubahan jika terdapat kebijakan baru yang dihasilkan dari sebuah proses yang cukup panjang.

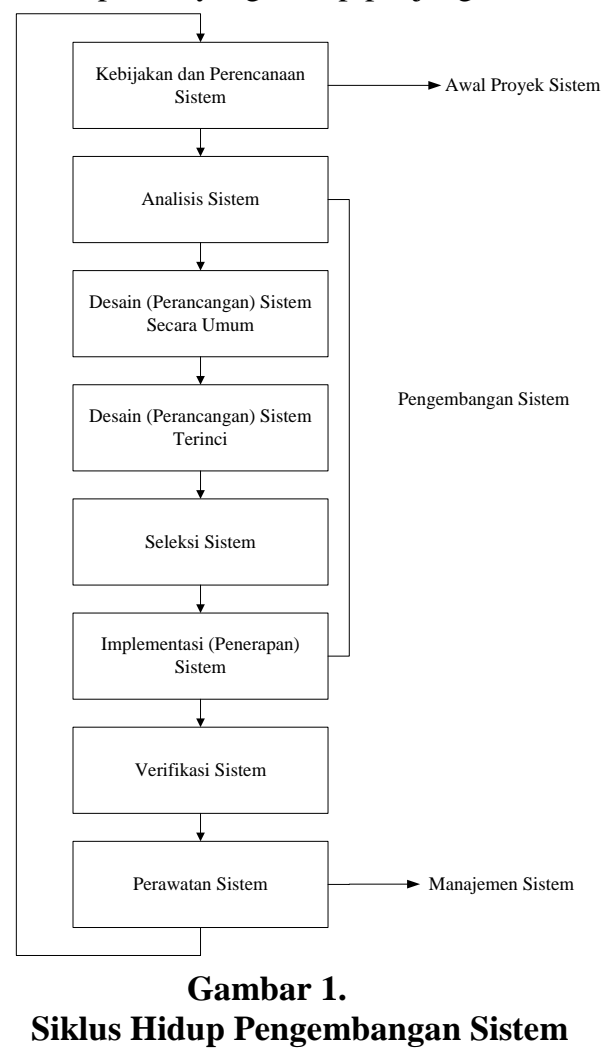

\section{Review Jurnal}

Terdapat beberapa acuan penelitian yang dijadikan referensi dalam penelitian kali ini. Adapun referensi tersebut adalah: 
1. Pada tahun 2009 Surono melakukan penelitian dengan objek penelitian di SMA Tugu Cawas Klaten dengan hasilnya berupa sistem administrasi sekolah yang terkomputerisasi. Dengan adanya sistem administrasi yang terkomputerisasi tersebut, membuat sistem administrasi memiliki nilai informasi yang cepat, tepat, akurat dan relevan [7].

2. Pada tahun 2012 Slamet dkk melakukan penelitian mengenai sistem informasi administrasi dengan menggunakan metode SDLC pada objek dinas kependudukan dan pencatatan sipil kabupaten Garut. Adapun hasil dari penelitian ini adalah dengan adanya sistem informasi administrasi kependudukan, maka bagian admnistrasi kependudukan dapat lebih mudah untuk mengelola data penduduk terutama data penduduk pindah, penduduk datang dan laporan-laporan. Selain itu, hasil penelitian ini juga menunjukan bahwa kualitas informasi yang dihasilkan menjadi lebih tepat, akurat, relevan dan sesuai dengan yang diharapkan [6].

3. Syahbana dkk pada tahun 2012 melakukan penelitan tentang sistem informasi administrasi dengan objek yang digunakan adalah Madrasah Aliyah Ma'arif Pacitan. Hasil yang didapatkan dari penelitian ini adalah suatu sistem informasi administrasi yang mendukung kegiatan pembayaran administrasi seperti sistem input pembayaran SPP, sistem input siswa baru, sistem input pembayaran insidental. Selain itu, penelitian ini menghasilkan sebuah sistem yang mempermudah dalam pencarian data siswa yang diperlukan dan juga mempercepat proses pembuatan laporan yang tidak menghilangkan nilai ketepatan dan relevansi datanya [8].

4. Pada tahun 2012 Yuanita melakukan penelitian mengenai sistem informasi administrasi dengan objek yang dikajinya adalah taman kanak-kanak negeri Pembina di kecamatan Pringkuku. Penelitan ini menitik beratkan penelitian pada bidang informasi administrasi pembayaran dana sumbangan pendidikan (DSP) dan administrasi pembayaran iuran bulanan (SPP). Dengan adanya sistem informasi yang diperbaharui ini, maka permasalah sistem administrasi pembayaran yang kurang efektif dan efisien dapat diatasi, sehingga dalam menentukan keputusan dapat lebih cepat.
Efektifitas dan efisiensi yang lebih baik ini disebabkan karena proses pencatatan berulang-ulang yang menyebabkan proses menjadi lama dapat diatasi [9].

\section{PEMBAHASAN}

\section{Sistem Berjalan}

Berdasarkan hasil observasi pada bagian administrasi, maka sistem administrasi mahasiswa yang meliputi proses input data pribadi mahasiswa, input data nilai mahasiswa dan proses pembuatan laporan pada Universitas Kebangsaan Bandung dapat dijabarkan sebagai berikut:

\section{Proses Input Data Pribadi Mahasiswa.}

Mahasiswa yang mendaftar ke Universitas Kebangsaan mengisi formulir pendaftaran untuk selanjutnya dibuatkan rekapannya oleh bagian administrasi. Hasil masukan formulir mahasiswa tersebut kemudian dihasilkan Formulir Pembayaran (FP) dan Kartu Studi Mahasiswa (KSM) yang dibuat rangkap 2. KSM rangkap pertama diberikan kepada mahasiswa untuk mengetahui matakuliah apa saja yang diambil mahasiswa pada semester berjalan, sedangkan KSM rangkap kedua diarsipkan dan dijadikan acuan dalam pembuatan daftar mengajar untuk dosen.

\section{Proses Input Data Nilai Mahasiswa}

Proses ini diawali diserahkannya berkas nilai mahasiswa dari dosen yang bersangkutan kepada pihak administrasi. Selanjutnya berkas nilai tersebut diarsipkan. Ketika mahasiswa dating dan membutuhkan informasi maka bagian administrasi akan mencarinya pada arsip nilai tersebut.

\section{Proses Pembuatan Laporan}

Proses pembuatan laporan dilakukan oleh bagian administrasi setiap bulannya berdasarkan arsip yang ada. Laporan tersebut selanjutnya diberikan kepada rektor sebagai bahan dalam pengambilan keputusan.

Berikut ini dijelaskan Diagram Alir Data dari sistem yang berjalan di bagian administrasi Universitas Kebangsaan Bandung. 


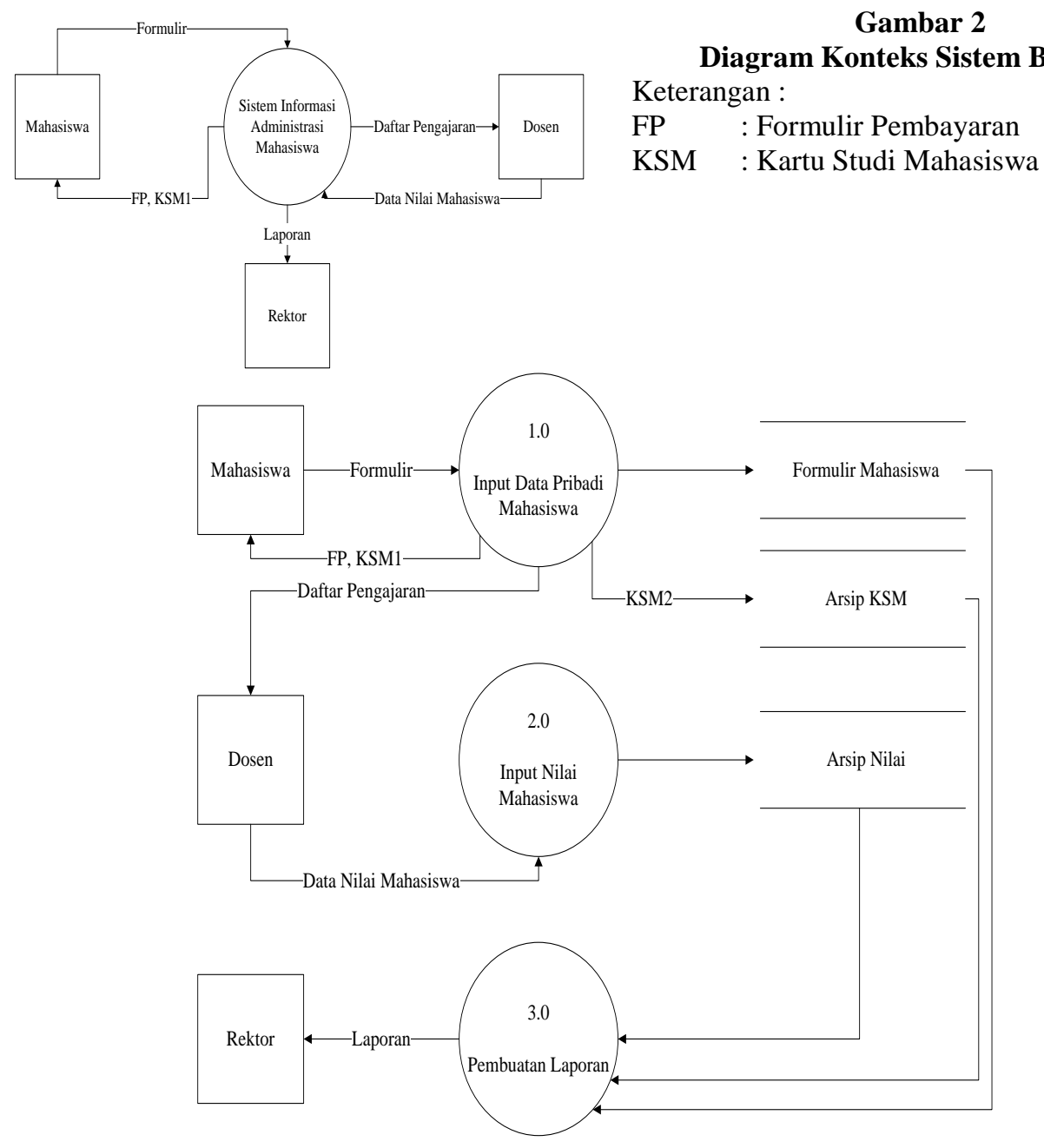

Gambar 3

Diagram Nol Sistem Berjalan

Keterangan :

FP : Formulir Pembayaran

KSM : Kartu Studi Mahasiswa 
Jurnal Informatika. Vol. I No. 2 September 2014

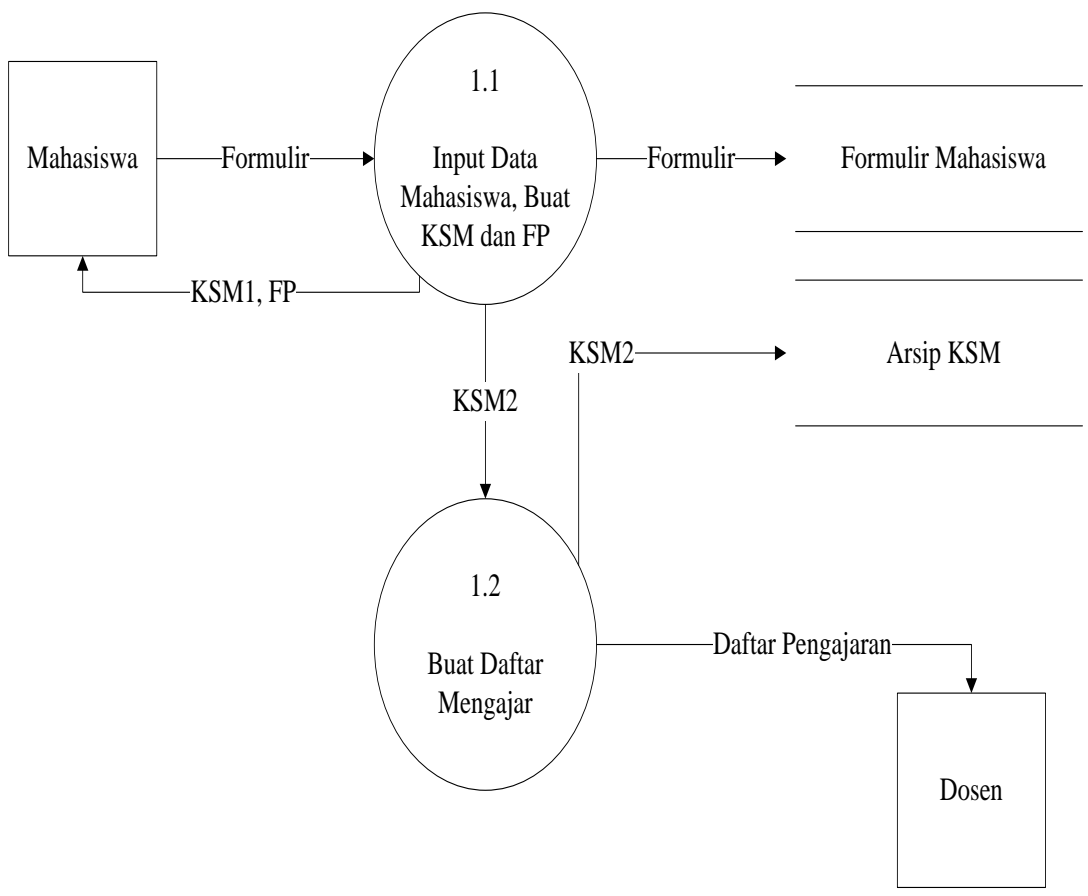

Gambar 4

Diagram Detail Proses 1.0 Sistem Berjalan

Keterangan :

FP : Formulir Pembayaran

KSM : Kartu Studi Mahasiswa

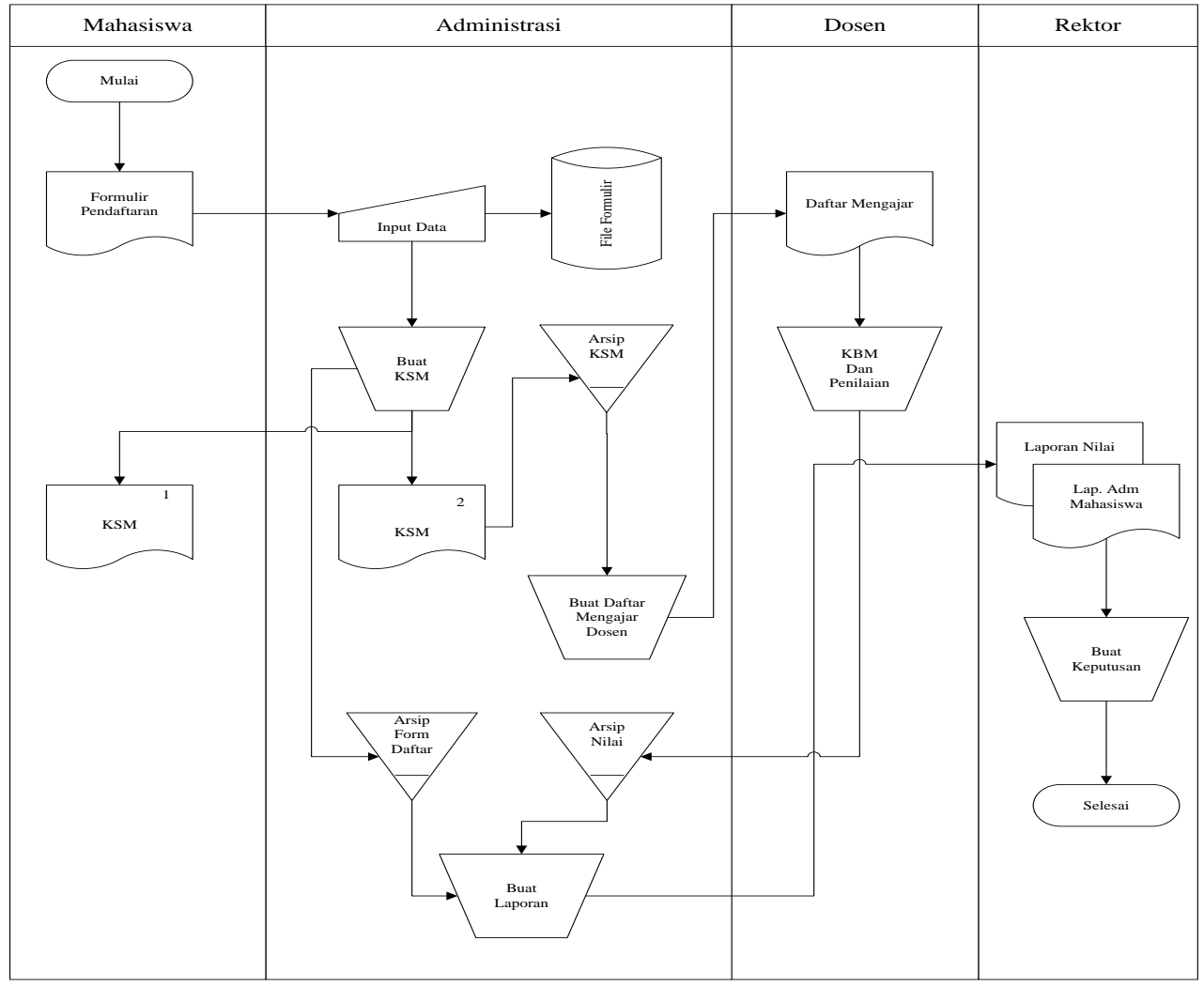

Gambar 5

Diagram Alir Dokumen Sistem Berjalan 


\section{Sistem Usulan}

Berdasarkan hasil analisa pada penelitian kali ini, maka diusulkan sistem baru yang diharapkan dapat meningkatkan tingkat efisiensi dan efektivitas dari kinerja administrasi. Adapun sistem usulan yang diajukan dijabarkan sebagai berikut:

\section{Proses Input Data Pribadi Mahasiswa}

Proses masukan data pribadi mahasiswa diawali dengan diterimanya formulir mahasiswa oleh bagian administrasi untuk selanjutnya dibuatkan rekapnya. Data mahasiswa tersebut disimpan di database dan arsip sebagai data utamanya. Hasil input data formulir kemudian dibuatkan formulir pembayaran dan Kartu Studi Mahasiswa (KSM) yang dibuat rangkap 2. Rangkap pertama diberikan kepada mahasiswa sebagai acuan perkuliahan semester berjalan, sedangkan KSM rangkap kedua disimpan dalam bentuk file dan arsip sebagai bahan acuan pembuatan daftar pengajaran untuk dosen.

\section{Proses Input Data Nilai Mahasiswa}

Proses ini dimulai dengan diserahkannya berkas nilai mahasiswa dari dosen yang bersangkutan kepada pihak administrasi. Selanjutnya berkas nilai tersebut dimasukan kedalam sistem komputer untuk diberikan grade dan disimpan dalam bentuk file dan arsip nilai mahasiswa. Ketika ada mahasiswa datang untuk melakukan kroscek nilai, maka keseluruhan nilai yang didapat dari dosen dapat diketahui dengan rinci melalui dokumen KHS yang akan dicetak bila timbul permintaan dari mahasiswa.

\section{Proses Pembuatan Laporan}

Pembuatan laporan dilakukan setiap bulannya dengan menggunakan data yang terdapat pada file komputer. Hal ini dilakukan hanya dengan memasukan periode tanggal awal dan tanggal akhir setiap bulannya.

Untuk lebih jelasnya, arus data yang mengalir pada sistem usulan ini dijelaskan pada diagram alir data dan flowchart berikut ini.

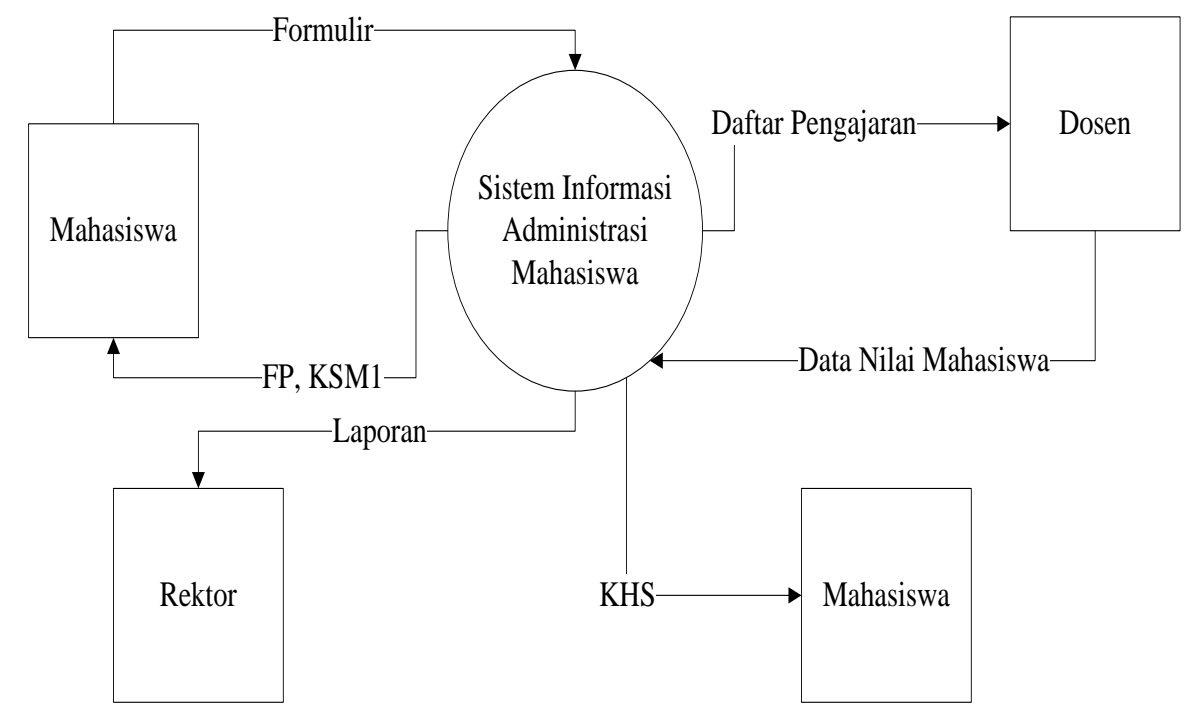

Gambar 6

Diagram Konteks Sistem Usulan

Keterangan :

FP : Formulir Pembayaran

KSM : Kartu Studi Mahasiswa

KHS : Kartu Hasil Studi 


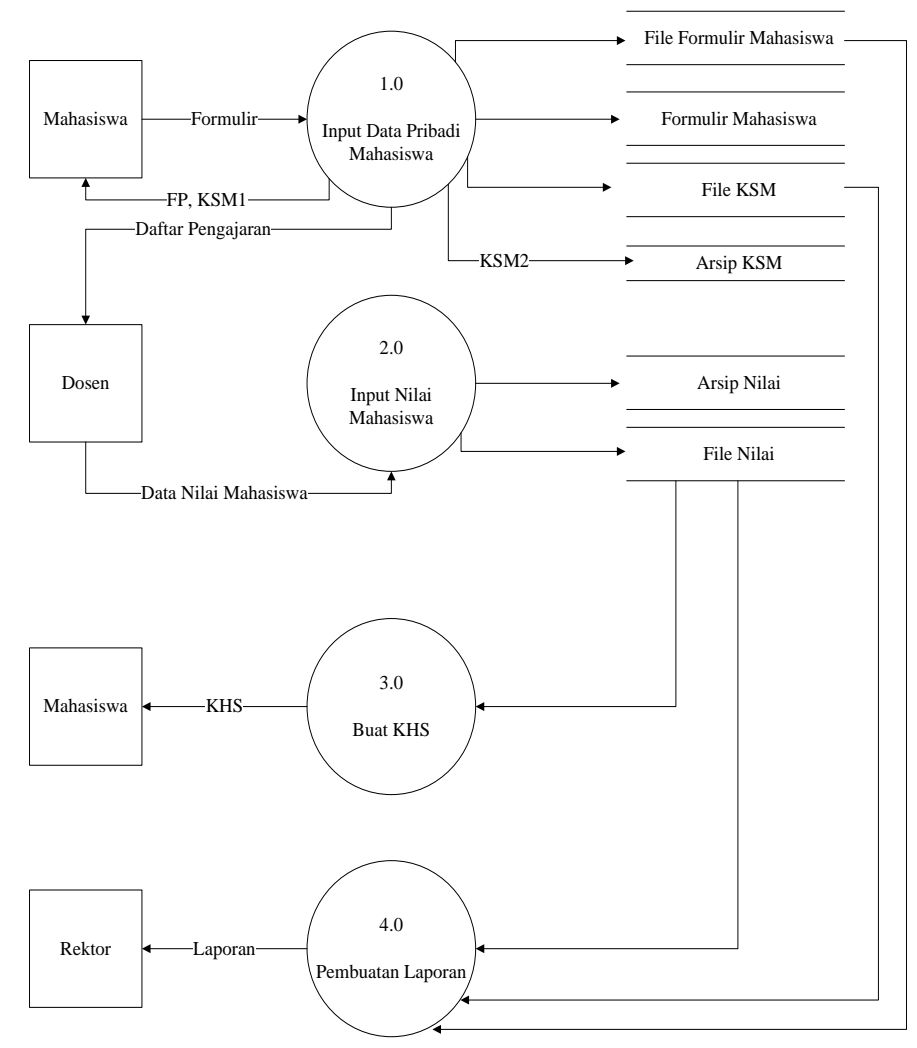

Gambar 7

Keterangan :

\section{Diagram Nol Sistem Usulan}

FP : Formulir Pembayaran

KSM : Kartu Studi Mahasiswa

KHS : Kartu Hasil Studi

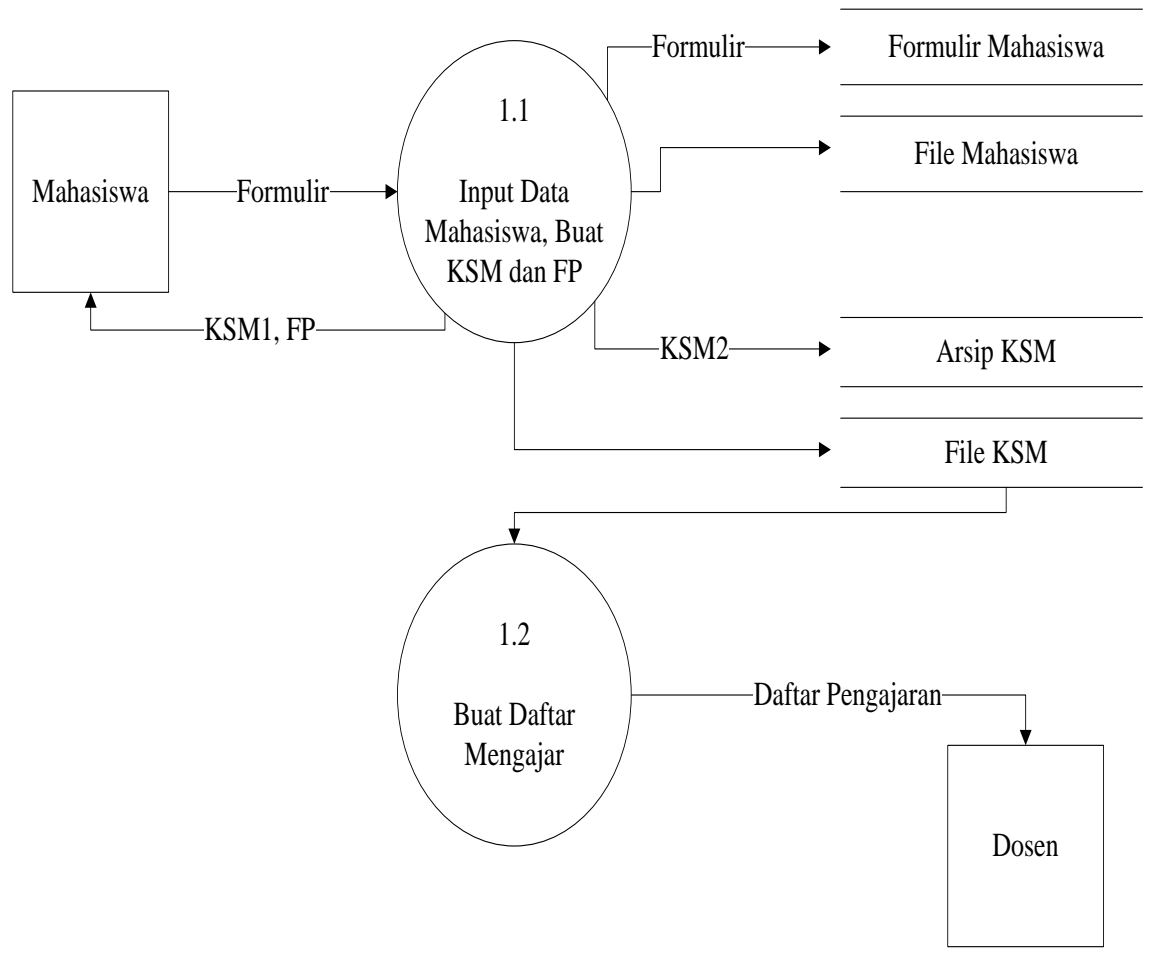

Gambar 8

Diagram Detail 1.0 Sistem Usulan 
Keterangan :

FP : Formulir Pembayaran

KSM : Kartu Studi Mahasiswa

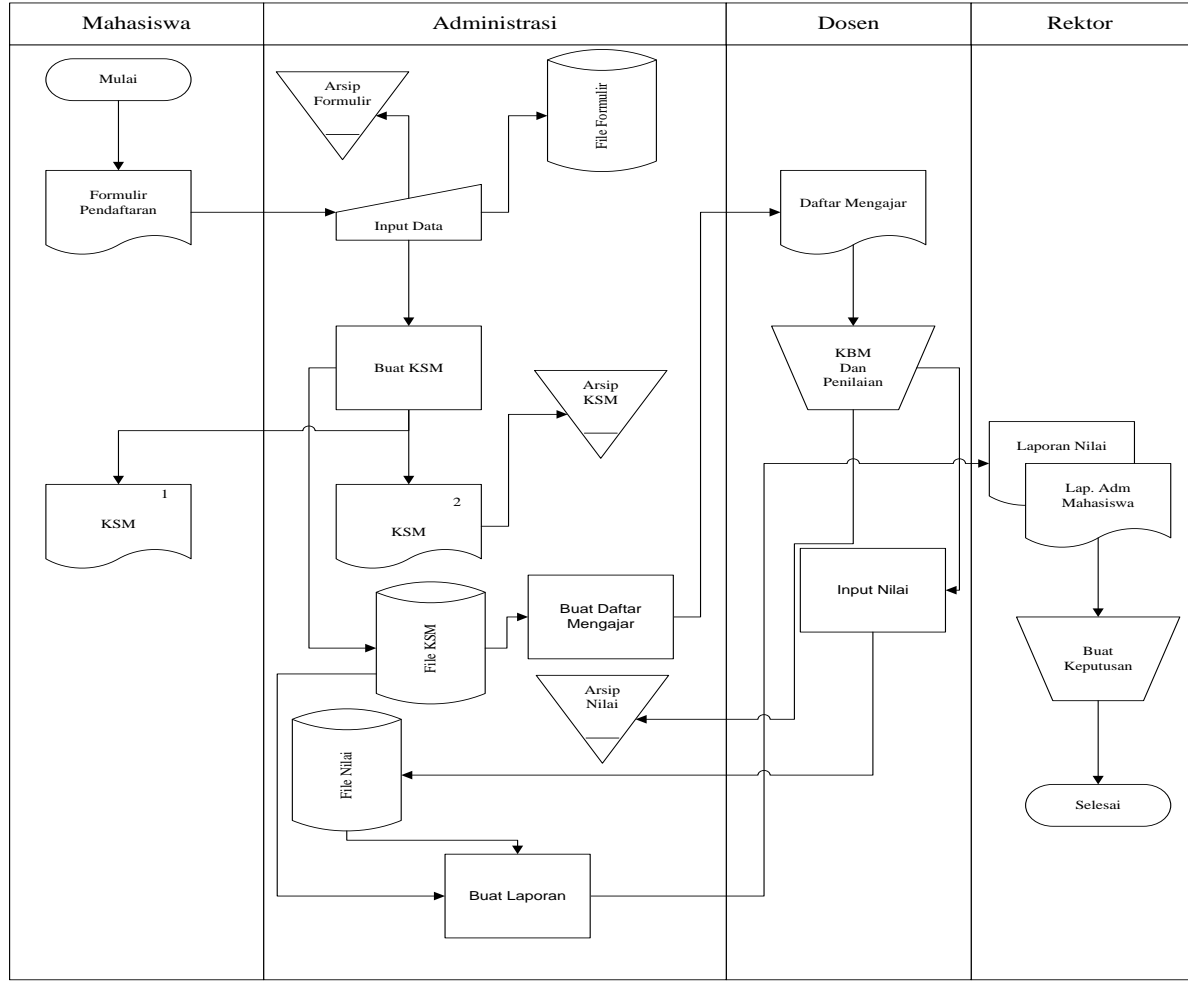

Gambar 9

Diagram Alir Dokumen Sistem Usulan

1. Perancangan Desain Interface

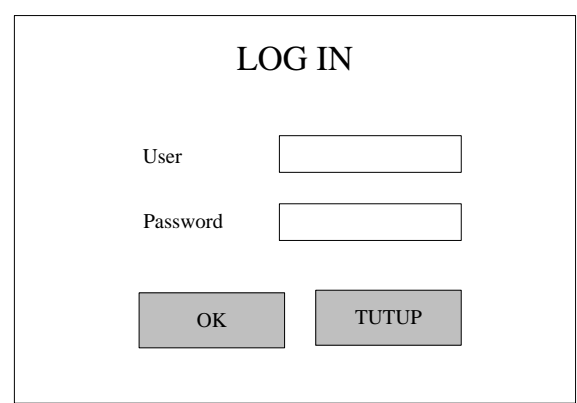

Gambar 10

Desain Tampilan Log In Admin

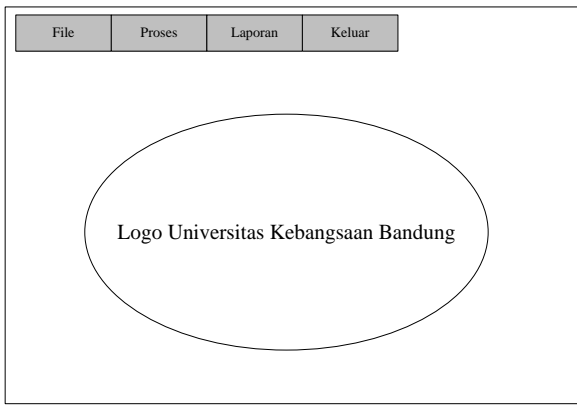

Gambar 11

Desain Tampilan Menu Utama

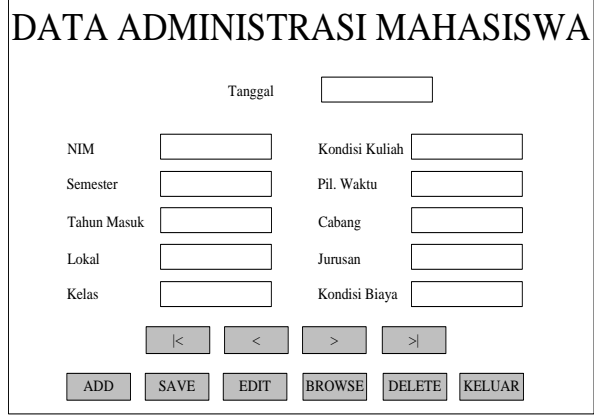

Gambar 12

Desain Tampilan Menu Input Data Administrasi Mahasiswa

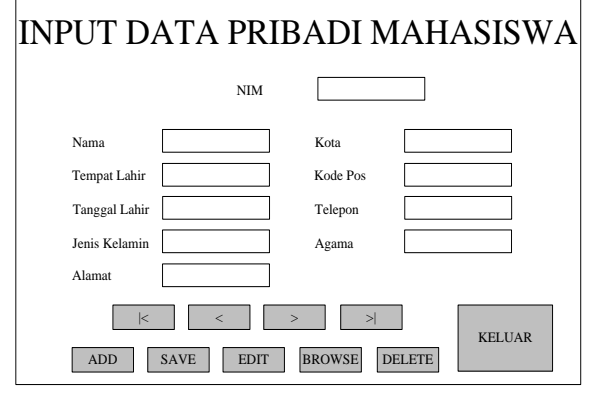

Gambar 13. 
Desain Tampilan Menu Input Data Pribadi Mahasiswa

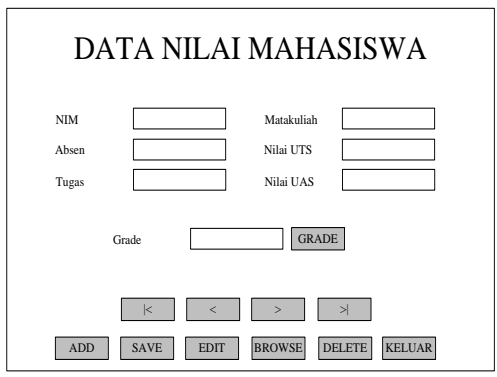

Gambar 14

Desain Tampilan Menu Olah Data Mahasiswa

2. Implementasi

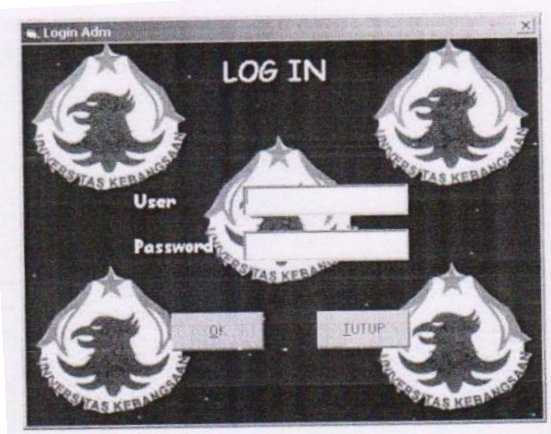

Gambar 15

Tampilan Log In Admin

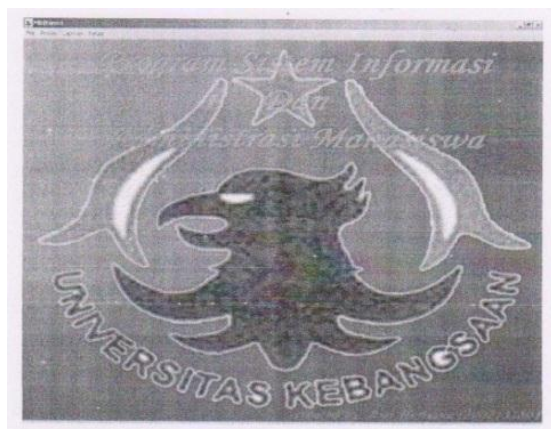

Gambar 16

Tampilan Menu Utama

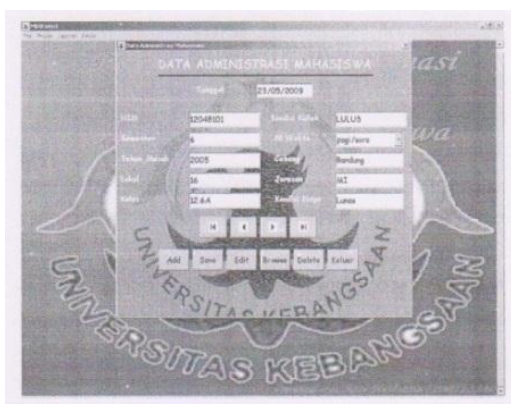

Gambar 17
Tampilan Menu Input Data Administrasi Mahasiswa

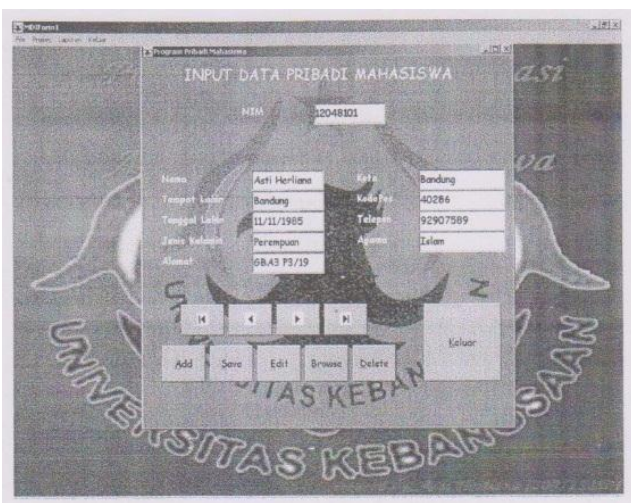

Gambar 18

Tampilan Menu Input Data Pribadi Mahasiswa

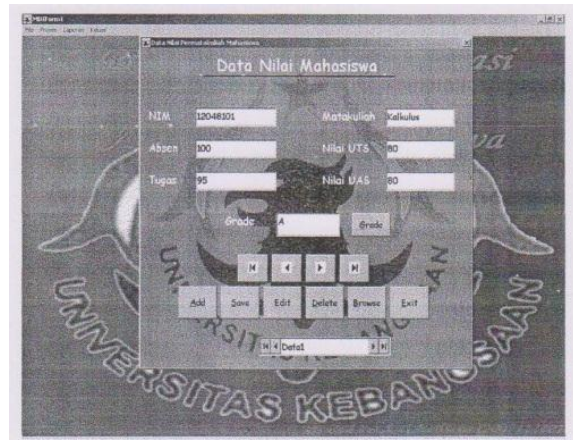

Gambar 19

Tampilan Menu Olah Data Mahasiswa

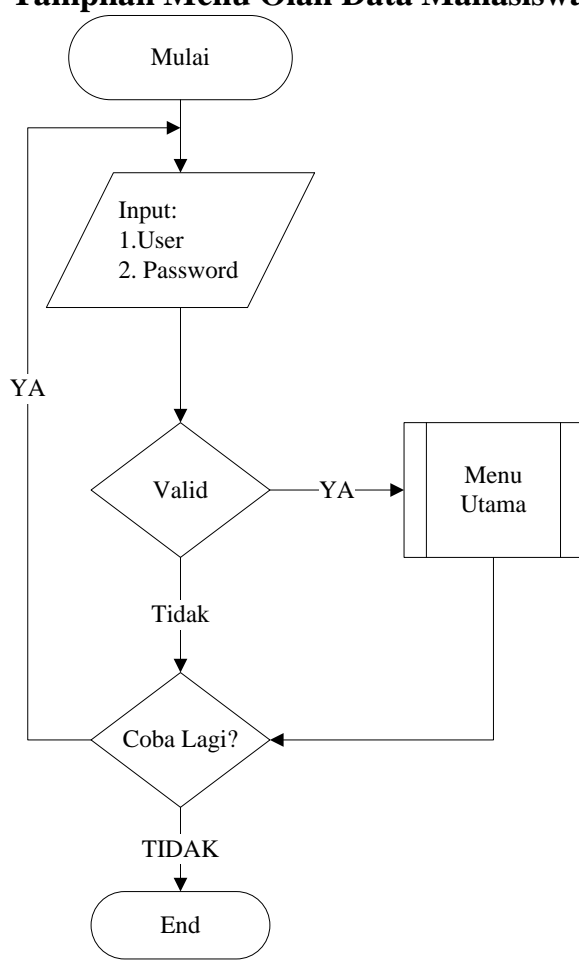

Gambar 20

Flowchart Program Login 


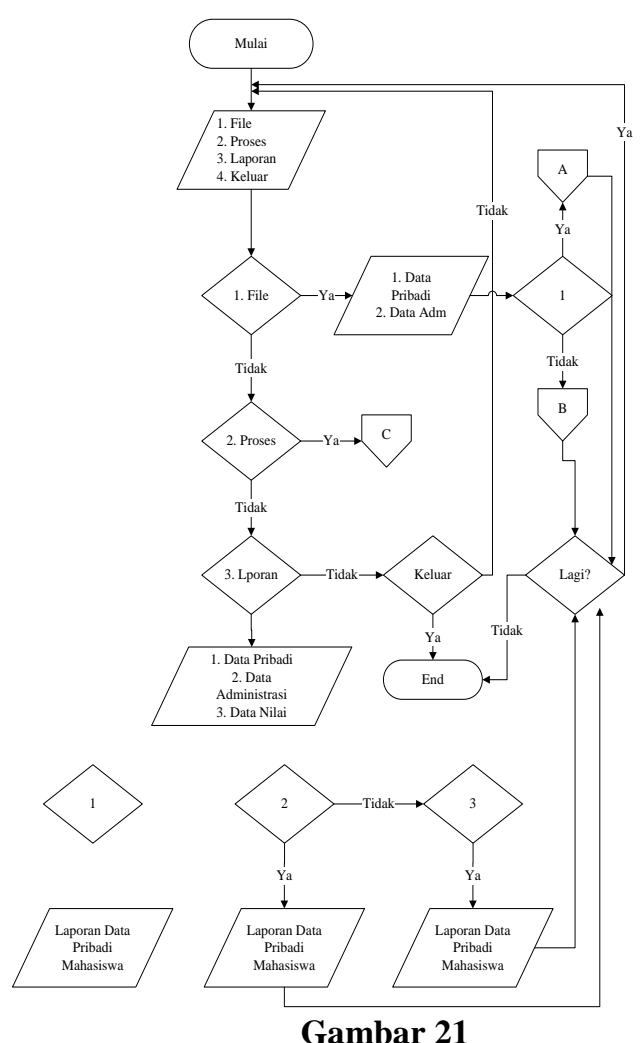

Flowchart Program Menu Utama

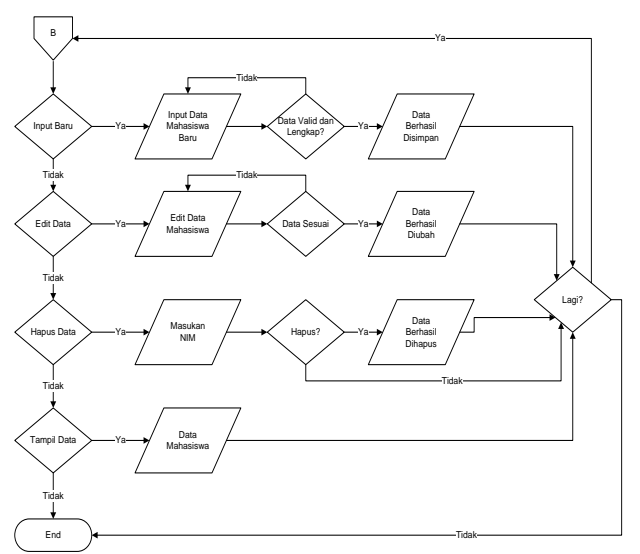

Gambar 23

Flowchart Program Input Data Administrasi Mahasiswa

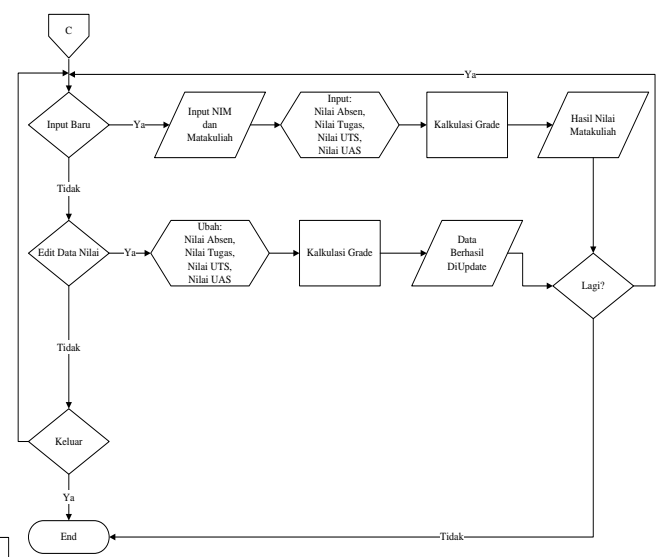

Gambar 24

Flowchart Program Input Data Administrasi Mahasiswa

\section{PENUTUP}

Kesimpulan

Berdasarkan hasil pembahasan, maka didapatkan beberapa kesimpulan sebagai berikut:

1. Sistem yang sudah terkomputerisasi belum tentu dapat memberikan kontribusi yang diinginkan apabila dalam penggunaan program tidak mengikuti setiap perkembangan yang terjadi.

Gambar 22

Flowchart Program Input Data Pribadi Mahasiswa
2. Sistem administrasi di perguruan tinggi merupakan salah satu sistem yang memerlukan sistem komputerisasi yang tepat guna, agar dapat mempermudah dalam kegiatan sehari-hari.

3. Sistem penyimpanan dengan menggunakan database lebih efektif dan efisien sebagai backup dari arsip, terutama dalam hal pembuatan laporan rutin. 
4. Program visual dapat dioperasikan lebih mudah oleh operator dibandingkan dengan program yang masih berbasis DOS.

5. Program visual lebih bisa diandalkan dalam hal pencarian data dalam waktu yang singkat, sehingga dapat mengefisienkan kinerja dari bagian administrasi.

\section{REFERENSI}

[1]Baridwan, Zaki. 1993. Sistem Informasi Akuntansi-Penyusunan Prosedur dari Metode. Edisi Kedua. BPFE. Yogyakarta.

[2]Dewi, Irra Chrisyanti. 2011. Pengantar Ilmu Administrasi. Prestasi Pustaka. Jakarta.

[3]Jogiyanto, HM. 2005. Analisis dan Desain Sistem Informasi. Edisi Ketiga. Andi Offset. Yogyakarta.

[4]Ladjamuddin, A. 2005. Analisa dan Desain Sistem Informasi. Graha Ilmu. Yogyakarta

[5]Siagian, P Sondang. 2004. Filsafat Administrasi. Bumi Aksara. Jakarta.

[6]Slamet, Doni, Eko Retnadi dan Partono. 2012. Pengembangan Sistem Informasi Administrasi Kependudukan (SIAK) pada Bagian Pendaftaran Pindah Datang Penduduk di Dinas Kependudukan dan Pencatatan Sipil Kabupaten Garut. Jurnal Algoritma Sekolah Tinggi Teknologi Garut, Vol 09, No 04, ISSN : 2302-7339.

[7]Surono, Budi. 2009. Analisis dan Perancangan Sistem Informasi Administrasi Sekolah pada SMA Tugu Nasional Cawas Klaten. Final Project. Fakultas Teknik STMIK AMIKOM. Yogyakarta.

[8]Syahbana, Ali, Bambang Eka Purnama dan Sukadi. 2012. Pembangunan Sistem Informasi Administrasi Pembayaran Siswa Madrasah Aliyah Ma'Arif Pacitan. Jurnal Speed 13 Vol 9 No 2. Universitas Surakarta.

[9]Yuanita, Sukadi. 2012. Sistem Informasi Administrasi Pembayaran Iuran Bulanan (SPP) dan Dana Sumbangan Pendidikan (DSP) Siswa Taman Kanak-Kanak Negeri Pembina Kecamatan Pringkuku. Jurnal Speed 13 Vol 9 no 2. Universitas Surakarta.
[10]Zulkifli, Amsyah. 1997. Manajemen Sistem Informasi. PT. Gramedia Pustaka Utama. Jakarta.

\section{Tentang Penulis}

Asti Herliana lahir di kota Bandung pada tanggal 11 November 1985. Anak kedua dari pasangan Bpk Erie Heryanto dan Ibu Elih Carlia (Alm) ini adalah Istri dari Willy Fauzi Syafrulloh dan Ibu dari seorang putri cantik yang bernama Habibah Azreen Syahilla ini. Bekerja sebagai staff pengajar di Bina Sarana Informatika sejak tahun 2007, telah menyelesaikan program diploma 3 di Bina Sarana Informatika, program ekstensi Sarjana di Universitas Kebangsaan Bandung dan juga telah lulus pada program Magister Ilmu Komputer di STMIK Nusa Mandiri pada tahun 2013. 